This item was submitted to Loughborough's Research Repository by the author.

Items in Figshare are protected by copyright, with all rights reserved, unless otherwise indicated.

\title{
Employee share ownership, psychological ownership, and work attitudes and behaviours: A phenomenological analysis
}

\section{PLEASE CITE THE PUBLISHED VERSION}

http://dx.doi.org/10.1111/joop.12146

\section{PUBLISHER}

(c) The British Psychological Society. Published by Wiley.

\section{VERSION}

AM (Accepted Manuscript)

\section{PUBLISHER STATEMENT}

This work is made available according to the conditions of the Creative Commons Attribution-NonCommercialNoDerivatives 4.0 International (CC BY-NC-ND 4.0) licence. Full details of this licence are available at: https://creativecommons.org/licenses/by-nc-nd/4.0/

\section{LICENCE}

CC BY-NC-ND 4.0

\section{REPOSITORY RECORD}

McConville, David, John Arnold, and Alison Smith. 2016. "Employee Share Ownership, Psychological Ownership, and Work Attitudes and Behaviours: A Phenomenological Analysis". Loughborough University. https://hdl.handle.net/2134/20650. 
Psychological Ownership and Employee Share Ownership

Running head: Psychological Ownership and Employee Share Ownership

Employee share ownership, psychological ownership, and work attitudes and behaviours: A phenomenological analysis

David McConville

National Sun Yat-sen University, Taiwan

John Arnold

Loughborough University, UK

\author{
Alison Smith \\ Nottingham Trent University, UK
}

\begin{abstract}
Acknowledgement
The authors would like to acknowledge with thanks the financial support provided to the study by ifs Proshare, BT and PricewaterhouseCoopers (PwC).The authors would also like to thank the ESO Administrators who helped in attracting companies to participate in the study.
\end{abstract}

Keywords:

Psychological ownership, employee share ownership, control, knowledge, investment. 


\begin{abstract}
This study uses qualitative data to explore how employees perceive the relationships between employee share ownership (ESO) scheme participation, their attitudes and behaviours at work, and their feelings of psychological ownership (PO). We contribute to two areas of (largely quantitative) research literature. First, we advance understanding of PO by examining participants' explanations of how they feel their sense of PO is affected by participating in a company ESO scheme. Second, we examine the role of PO in employees’ explanations of the attitudinal and behavioural changes they feel they have experienced as a consequence of participating in an ESO scheme. To explore the subjective meaning of ESO participation and its PO impact, 37 semi-structured interviews were conducted in nine companies with participants in three tax-advantaged ESO schemes in the United Kingdom: SIP, SAYE and EMI. Data were coded and analyzed using thematic analysis (Braun \& Clarke, 2006). Participants perceived little effect of ESO schemes on PO or on the organizational features anticipated to give rise to these feelings. In turn, PO was found to play little or no part in employees’ explanations of how share schemes had, or did not have, an attitudinal or behavioural impact.
\end{abstract}




\section{Practitioner Points}

- Interviewees reflected on their experiences of joining employee share ownership (ESO) schemes, holding options, exercising options and owning shares in the company. There was very little evidence that employees felt that any of these stages of ESO participation had any noticeable effect on their feelings of psychological ownership (PO). Other factors seemed to satisfy PO routes before, and possibly better than, ESO.

- PO played little or no part in employees' explanations of how the ESO scheme impacted upon their attitudes or behaviours.

- The findings contrast with the conventional wisdom, that participating in an ESO scheme inevitably causes employees to feel a sense of ownership over the company.

- We find that ESO had very little to do with ownership in the minds of employees. Instead, it was much more about investment. ESO was not seen as a mechanism for employees to have a sense of ownership over the company and employees did not appear to regard ESO as providing experiences of the three ownership rights, or the routes to PO which parallel these. 


\section{Employee share ownership, psychological ownership, and work attitudes and behaviours: A phenomenological analysis}

\section{Introduction}

This paper reports a qualitative study which develops understanding of how employees interpret and make sense of the relationship between psychological ownership (PO) and employee share ownership (ESO) schemes. Although links between ESO and PO have been theorized in the research literature (Pierce, Rubenfeld, \& Morgan, 1991), few studies have empirically explored this relationship and little is known about whether ESO's impact on participants' attitudes and behaviours can be illuminated by using theories of PO. Typically, studies of ESO rely on quantitative survey data, rarely utilizing qualitative data to explore how employees feel when participating in an ESO scheme; how they describe the causes and effects of ownership feelings, or how the features of their job and life at work interact with these feelings.

A number of writers have stressed the need to consider ESO schemes more closely (e.g. Kaarsemaker, Pendleton \& Poutsma, 2010; Poutsma, Kalmi \& Pendleton, 2006; Sengupta, Pendleton \& Whitfield, 2010) and to consider alternatives to the quantitative methods currently dominating the ESO literature (e.g. Knyght, Kouzmin, Kakabadse \& Kakabadse, 2010; Sengupta et al., 2010). This study addresses this, by taking a qualitative approach aiming to gauge employees' experiences of three different ESO schemes in the UK. In particular, the discussion reflects on a dominant theory of how PO is believed to develop. Pierce, Kostova and Dirks' (2001, 2003) theory of 'PO routes' suggests that certain experiences (known as routes) are likely to produce feelings of PO. In the analysis and discussion presented in the current paper, consideration is given to how employees make sense of the elements of this theory. 
To advance understanding of PO and its interactions with ESO this paper reports qualitative research within the phenomenological psychological model. This is used to discuss (i) if, and (ii) how employees feel ESO has affected their feelings of ownership, and whether these feelings of ownership have led to changes in the way they think, feel and behave, in relation to their job, the company, or any other aspect of their life at work. Similar to other studies in organizational psychology that have followed a phenomenological approach to the study of employee experiences (e.g. Millward, 2006; Poppleton, Briner \& Kiefer, 2008), the method used here is "based upon descriptions of experiences as they occur in everyday life” (Giorgi, 1995, p.39). Phenomenological approaches do not aim to find out about an external reality. Instead, the aim is to "understand the meaning (and structure) a conscious person has developed” (Willis, 2007, p. 173).

The themes presented in thefindings reflect how employees make sense of their feelings of PO and their ESO experiences. Instead of searching for universal truths, the researchers aim to uncover individual and contextualized understanding. Husserl, one of the founders of the phenomenological approach (see Lopez \& Willis, 2004) argued that subjective information is important when seeking to understand human motivation because human actions are influenced by what people perceive to be real. A key contribution made in this study resides in the identification of what employees themselves feel makes sense, and how they interpret and explain their experiences of participating in a company share scheme and their feelings of ownership. Whilst the study cannot take a purely inductive approach (prior knowledge of PO and ESO theory precludes this) the researchers aim to avoid imposing theory on the data and instead allow participants to say what they feel is important. The researchers do not ignore theoretical suggestions and research findings found in earlier studies, but also allow themes (including unexpected findings) to emerge from the data. 
Examining whether dominant models are likely to be plausible to people and fit with their subjective experience has potentially very valuable implications for practice, not least because attempts to promote ESO are likely to be more effective if they speak to people's subjective understandings. The discussion is therefore used to examine the data in the context of existing research literature, and discuss the affinities between participants' sense-making and current theories of PO.

\section{Psychological Ownership and Employee Share Ownership}

\section{Psychological Ownership}

PO answers the question "What do I feel is mine?” (Pierce et al., 2003, p. 86). It is the "state in which individuals feel as though the target of ownership (material or immaterial in nature) or a piece of that target is 'theirs'. Pierce at al. (2001, p. 299) described PO as “the feeling of being psychologically tied to an object” (material or immaterial), where possessions feel like extensions of the self (i.e. it is not only mine, it is part of me). A person experiencing feelings of PO may not legally own the object they feel possession over. It is also possible that individuals legally own an object, but feel little or no ownership over it. In recent years PO has gathered momentum and a range of definitions of PO can now be found (e.g. Avey, Avolio, Crossley \& Luthans, 2009; Chiu, Hui \& Lai, 2007; Pendleton et al., 1998; Pendleton, 2001; Wagner, Parker \& Christiansen, 2003). A possession-based measurement focusing on feelings of MINE and OURS (VandeWalle, Van Dyne \& Kostova, 1995), drawing extensively on studies of possession (e.g. Furby, 1978; Rudmin \& Berry, 1987) has been operationalized, validated and tested more frequently than others (e.g. by Brown, Pierce \& Crossley, 2013; VandeWalle et al., 1995, and Van Dyne \& Pierce, 2004). We therefore focus on a possession based definition of PO. 


\section{Employee Share Ownership}

The purpose of an ESO scheme is "to provide benefits to employees in the nature of shares in a company, which give them a continuing stake in that company” (The [United Kingdom (UK)] Finance Act 2000, Schedule 8, Part 2). Kaarsemaker et al. (2010) identify two main categories of employee ownership. The first, majority ESO, refers to a majority employeeowned firm. The second form can be termed mainstream ESO, where employees receive shares or share options on preferential terms but do not collectively own the company. The sponsors of this study expressed their interest in understanding more about the impact of three different mainstream share schemes in the UK. SAYE (Save as you Earn, also known as Sharesave), SIP (Share Incentive scheme), and EMI (Enterprise Management Incentives). Scheme descriptions appear in Appendix 1.

\section{ESO and the Routes to Psychological Ownership}

Pierce et al. (2001, 2003) have proposed that experiences leading to feelings of PO, known as 'the routes', arise from certain processes of association of the individual with a target (that which the individual feels ownership over, such as the employing organization or job). The three routes to PO are (a) the amount of control an employee has over the target (control), (b) the extent to which an employee intimately knows the target (intimate knowledge), and (c) the extent to which individuals invests themselves into the target (investment of the self). Measures of these routes can be found in Brown et al. (2013). Pierce et al. (2001) suggested that there is a positive and causal relationship between the three routes and the degree of ownership the employee feels toward the target.

Pierce et al. (1991, p. 125) also suggested that ownership can be defined in terms of three basic and fundamental rights, “each of which may be more or less present in certain employee ownership contexts”. They include the right to possess a share of the owned object's physical being and/or financial value (equity), the right to information about the 
status of that which is owned (information), and the right to exert influence or control over the owned object (control). Pierce and Rodgers (2004a) and Chi and Han (2008) have argued that an ESO arrangement constructed around these three rights, parallels the three routes to PO. The SAYE, SIP and EMI plans all ultimately provide employees with an opportunity to own shares (equity) in the company. Some obvious links can be made between ESO and what Pierce et al. (1991) refer to as ‘information’ and ‘control’ rights. In addition to owning options or shares in the company, participating in an ESO scheme is believed to create “expectations among employees in terms of their influence over firm decision-making and their legal rights” (McCarthy \& Palcic, 2012, p. 3712). Potentially satisfying these expectations, ESO can provide explicit governance rights, including the right to vote on company resolutions and invitations to attend the company annual general meeting (Pendleton \& Robinson, 2011). Furthermore, during mergers, acquisitions and takeovers, shareholders have important information and decision rights (Pendleton \& Robinson, 2011) and are able to monitor share price performance and track the value (or potential value - if they hold share options) of their investment. As shareholders (and option holders), employees have access to "frequent feedback of economic results" (Pierce at al. 1991, p. 125). A potential connection between ESO and the way in which PO may emerge through the PO routes can therefore be identified.

Pierce et al. (2003) proposed that any single route to PO can result in feelings of ownership. This would suggest that in order to influence feelings of PO, ESO may not need to provide the participant with experiences (i.e. equity, information and influence rights) that satisfy all three routes. However, Pierce and colleagues argue that feelings of ownership for a particular target will be strongest when all three routes are operating, and that control and investment of self in the target may be more potent than intimate knowledge. Very little empirical evidence is available regarding what the most effective routes may be, or ESO's 
potential to enhance a possession based definition of PO (those that have include Bernhard \& O'Driscoll, 2011; Brown et al., 2013; Chi \& Han, 2008; McCarthy \& Palcic, 2012). Despite Pierce et al.’s (1991) theoretical work depicting a relationship between ESO and PO, no known study has explored with employees how they make sense of their ESO experiences and feelings of ownership.

\section{Attitudinal and Behavioural Effects of Psychological Ownership}

A number of empirical studies (e.g. Mayhew et al., 2007; O’Driscoll et al., 2006; Sieger, et al., 2013) and also theoretical papers (e.g. Pierce et al., 2001, 2003) have explored the attitudinal or behavioural outcomes of PO. Whilst affective commitment has been investigated in some PO studies, continuance and normative components of commitment have been examined less frequently as outcomes of PO. There is however, some evidence supporting PO’s relationship with both continuance and affective commitment (e.g. Mayhew et al., 2007; O’Driscoll et al., 2006; VandeWalle et al., 1995; Van Dyne et al., 2004). In relation to employee motivation, Pierce et al. (1991) suggested the perception of gains and losses associated with the employees’ current or future equity, as well as their influence and informational rights, may have a motivational effect. However, PO’s capacity to enhance employee motivation is another area in which research evidence is lacking. Similarly, a small number of studies have attempted to test PO’s relationship with employee satisfaction. Van Dyne et al. (2004) and VandeWalle et al. (1995) found that job satisfaction and PO for the organization (i.e. this is "MY” company) had a moderately strong, positive relationship. Mayhew et al. (2007) found that both job based (i.e. this is "MY” job) and organization based PO were significantly related to job satisfaction. Whilst most PO studies find positive effects, not all do. McCarthy and Palcic (2012) found in their study of PO's effect on productivity that, despite the substantial shareholding in the case study company, the employee ownership 
arrangement "failed to create a sense of PO among employees, and thereby further impact on productivity” (p. 3710). Employees in this study also did not feel that employee ownership improved participation in decision-making (the control route) in the organization. In cases such as this, it is possible that employees already felt PO, or that one of the routes (e.g. the control route) was not satisfied. Empirical evidence exploring why ESO may influence PO in some circumstances, and not others, is lacking.

\section{ESO's Effects: The Mediating Role of Psychological Ownership}

A small but influential set of studies theorize ESO can enhance employees' sense of PO, leading to changes in behaviour and attitudes. Pierce et al. (1991) presented a detailed model of ESO effects, proposing a number of intervening stages and moderating effects. According to Buchko (1992, p.715), this model, which positions PO as mediating the effects of ESO on attitudinal and behavioural outcomes, "represented an advance over previous efforts”. Different types or forms of ownership, according to Pierce et al. (1991), may moderate the relationship between ESO and the degree to which the employee owner identifies with and internalizes the organization. In SAYE, SIP and EMI schemes (see Appendix 1) employees may obtain voting rights but may not always feel this provides them with significant influence, especially in mainstream ESO. Little is known about what employees themselves identify as important factors in creating feelings of possession, what they expect when participating, or the extent to which they believe ESO can satisfy these feelings and expectations.

The phenomenological approach used here explores and understands ESO and PO through conversation, rather than hypothesis testing and provides new insights and explanations which help to facilitate the development of effective theory about the psychological effects and processes surrounding ESO. 


\section{Method}

An important consideration in qualitative research is the trustworthiness of the research process and the findings (Lincoln \& Guba, 1985; Guba \& Lincoln, 1994). According to Lincoln and Guba (1985, p. 43) trustworthiness in qualitative research includes four criteria: (1) credibility, (2) transferability, (3) dependability and (4) confirmability. To enhance credibility and dependability, it is important to ensure that methodological decisions are explained and justified according to standards agreed and accepted in qualitative research, and that the interviewees' thoughts and feelings are reflected as closely as possible in the findings. In the following sections of this paper we explain our research approach and our decisions relating to the methodology, sampling strategy, interview process and the analysis of data to provide a transparent account of the process undertaken, and the rationale.

To address transferability, we provide information about the individuals and companies so that judgments can be made about the range of settings to which our findings might apply. To help achieve this, Appendix 1 includes descriptions of the three UK Employee Share Ownership Schemes, sample criteria and characteristics of the chosen companies and employees (Table 1). The range of share schemes and organizations give some reason to suppose the findings might apply quite widely, with the obvious caveat that this research was confined to the United Kingdom.

Finally, the following sections also address confirmability. Attempts were made to not allow personal values or theoretical inclinations to "manifestly sway the conduct of the research and findings deriving from it” (Bryman, 2008, p. 379). As described in the following sections, participants were provided with the opportunity to talk about what they felt was 
important and communicate their own thoughts and feelings about their ESO experiences and feelings of ownership.

\section{Research Approach}

With reference to the phenomenological approach, Gioia et al. (2013) argue that there is value in semi-ignorance or enforced ignorance of the literature, and that knowing the literature can lead to prior hypothesis bias. In qualitative data collection, if the conceptual framework is constrained, so are the research questions (Miles \& Huberman, 1994). In having a broad research question, an idea about what may be important in explaining how ESO participants make sense of ESO (see Figure 1), and a semi-structured interview guide, this study lies between the two extremes of knowing and not knowing.

\section{Insert Figure 1 about here}

Phenomenological approaches do not aim to find out about an external reality, instead, the aim is to "understand the meaning (and structure) a conscious person has developed” (Willis, 2007, p. 173). As with other studies that have taken a phenomenological psychological approach to explore how employees make sense of their experiences (e.g. Millward, 2006), we do not assume a singular depersonalized reality and instead focus on employees' first-hand experiential accounts. During interviews, as employees make sense of their thoughts, feelings and behaviours, we are open to unexpected concepts and relationships which may emerge. Our loose conceptual framework presents the basis of what we seek to explore, that is, how employees make sense of ESO participation (in its different forms), and its effects (if any) on their attitudes, behaviours, and feelings of PO at work. Dominant theories of PO attempt to explain how specific experiences lead to ownership feelings (i.e. the 
routes to PO). We do not hypothesize how, or deductively test theoretical relationships. Instead we discuss with participants during semi-structured interviews how they themselves feel PO relates (or not) to their ESO experience.

\section{Procedure and Participants}

The non-probability sampling approach identified people who are likely to have information about the process being studied (Hornby \& Symon, 1994). Whilst variation amongst participants was achieved, companies and employees participating in the study depended to some extent on which ESO managers wanted to participate and the constraints on ESO participants' time. A number of different ESO plan administrators in the UK agreed to forward an electronic letter summarizing the study to ESO managers operating one or more of the three selected ESO schemes. Companies wishing to participate in the study then made contact with the researchers. Variation was sought not only in the ESO scheme operated, but also in other company level variables such as industry and longevity, and in employee-level variables such as age, gender, and earnings (see Table 1). ESO managers were asked to nominate four employees for interview, bearing in mind the selection criteria.

Insert Table 1 about here

As Table 1 indicates, our strategy resulted in the desired differences with regards to the plan interviewees participate in (which may provide the antecedents of PO in different ways), different levels of gross income (which may affect employees' interpretation of how significant their ownership share is), and differing lengths of service in the company (possibly providing different experiences of ESO over time, and varying degrees of PO). EMI and SAYE schemes do not give ownership in the first instance. At the time of interview some 
participants held shares in the company; others held share options. All were participating in an ESO scheme and all had owned and/or sold shares in an ESO plan at some point during their working lives. Participation in an ESO scheme includes joining the scheme, holding options, exercising options and owning shares in the company.

Over seven months (between 2009 and 2010) 37 audio recorded interviews with ESO participants of the SIP, SAYE and EMI plans took place in 9 different companies across the UK. Pilot interviews were conducted with employees who had participated (or were currently participating) in ESO schemes to assist in identifying ways to reword questions and translate the research topic into terms that the interviewee was able to relate to and discuss.

Each interviewee was provided with the opportunity to talk about what they felt was important, and to reflect on their experiences of ESO. Open questions were used wherever possible, and follow up questions and probes addressed specific concepts and relationships identified within interviewees’ narratives (see Rubin \& Rubin, 2005).

The processes through which people generate credible shared understandings of the situations they are in, is known as sense making (Cassell \& Symon, 2011). As with a number of other non-positivist approaches, we view interview data as a reflection of how employees, in conversation with the interviewer, constructed and made sense of their experiences. To address the research objective it was important to discuss with employees' their views on whether they felt they had experienced PO at work (over the company, their job, or both), whether employees felt participating in an ESO scheme had helped create PO, and how. In situations where employees perceived no impact, follow up questions explored whether employees believed ESO participation could have such an impact. Interviews inductively explored how employees described their experiences and feelings about ESO, PO, and any resulting attitudinal or behavioural effects. Whilst the literature suggests that employees would feel that PO (if experienced) was working through one or more of the three routes, we 
were open to the possibility that employees may not make reference to these routes during the process of the discussion. Only after employees had described and explained their experiences were they asked about these routes.

\section{Data Analysis}

To identify PO and the routes to it, we remained consistent with explanations and definitions provided in possession-based studies of PO (e.g. Brown et al., 2013; Pierce et al., 2001; 2003). The target of ownership was identified by examining what exactly the employee felt ownership over. Data were analyzed using a process of thematic analysis, described by Braun and Clarke (2006, p. 78) as “a flexible and useful research tool, which can potentially provide a rich and detailed, yet complex, account of data”. Thematic analysis can be described as a method for identifying, analyzing and reporting patterns within data that "can help to organize and describe data, and assist in interpreting” (Braun \& Clarke, 2006, p.79). Our approach shares some similarities with a number of previous studies analyzing qualitative data (e.g. Fenton-O’Creevy et al., 2011; McAlearney, 2006); our coding approach was both inductive and theoretical. Codes were developed following the identification of concepts and theories found in the literature (such as Pierce et al.'s 1991 model of ESO) and as a consequence of transcribing, reading, reflecting on, and discussing the interview data with co-researchers. The first author generated a draft set of initial codes on the basis of the research questions and the underlying theory, supplemented by a reading of interview transcripts. These, and their applicability to the transcripts, were discussed by all three authors, and a slightly revised set produced. Transcripts were then read and coded holistically to ascertain the presence/absence of PO; expectations of ESO, Equity Route, Knowledge and Information Route, Influence and Control Route, ESO Allocation and Procedure, Legitimacy of Participation in ESO, Integration into the Organization, Attitudes/Feelings at Work, 
Motivation, and Behaviours. Sub-themes (e.g. different forms of PO) were also defined as were relationships between themes. Additional coding techniques used included whether or not ESO was implicated (e.g. in feelings of control at work), and whether interview text reflected the positive (e.g. motivation) or negative (e.g. lack of motivation) pole of the theme.

Following the initial coding, segments of coded text were then considered in more detail. This recursive process resulted in codes being edited and new codes being added. For example, the code 'CIT' was used to identify evidence of, or reference to, organizational citizenship behaviour at work. Segments of data allocated this code were then explored more thoroughly and sub codes were used to identify how employees explained the reasons for this behaviour. In some cases this would be edited to the code "CIT/ESO", to indicate that the employee felt there was some link with ESO participation. Overarching themes and categories emerged from participants' stories and accounts of their ESO experiences. In doing this, we highlight as closely as possible the factors employees themselves identify as important when thinking about and explaining ESO’s psychological effects.

When determining codes, themes and coming to conclusions, discussion between authors was an important part of the analytical process (as also emphasized in FentonO’Creevy et al., 2011). Care was also taken to examine all text within the transcripts, including text not considered part of the main themes identified, to identify exceptional, infrequent and contradictory perspectives. Relationships between themes were also considered by the researchers in order to identify the overall picture arising from participants' accounts. In some instances it was clear during coding that people in the same organization were interpreting similar concepts in different ways. In these cases, re-coding was necessary. For example, a number of people used the concept 'commitment' as an explanation for how they felt (or didn’t feel) as a result of participating in the ESO plan. However, on probing 
what people meant by commitment, it was found that the same word was used to describe different types of commitment (as defined in the research literature).

\section{Results and Discussion}

Patterns and trends are presented using direct quotations from the interview data to reflect participants' perspectives. To begin, we present findings relating to how participants made sense of the relationship between ESO participation and feelings of PO.

\section{ESO Scheme Participation and Psychological Ownership}

Consistent with McCarthy and Palcic's (2012) study in an Irish telecommunications company, where employee ownership was not found to contribute to PO, we found that 27 employees felt that ESO had not impacted on their feelings of PO, compared with 10 who felt it had. Four participants reported that ESO enhanced their sense of PO over the company (company-based PO), three felt the scheme had enhanced their feelings of ownership over their job (job-based PO), and three both the company and the job. The extract below is from a discussion about ESO’s relationship with PO.

I am not sure how it (ESO) would have created a sense of ownership. Well, let's just think, if I had have made a lot of money out of it, would that have made me feel a sense of ownership? Probably not, no, it would probably have just made me feel a bit happier, in my personal life. I can't see a direct link between the performance of the share scheme and my personal sense of ownership. (EMI Participant, Company 7).

Many employees reported feeling PO at work, prior to, and/or irrespective of, ESO participation. These employees felt that PO had emerged for a number of reasons 
unconnected with ESO. Many stated they felt PO because they felt part of the company, proud to work for the company, had been employed for a long time in the company, and had developed a sense of belonging, a feeling of responsibility and feelings of task significance. Many employees cited the opportunity to participate in decision making or being part of a team:

I think being part of the senior management team makes me feel like it is my team. For me personally, I think that is a big factor. Having a role like this allows you some more ownership. (EMI Participant, Company 4).

In cases where the ESO scheme had an impact on feelings of PO, few employees were able to provide detailed explanations of how ESO had led to such a state of mind; and the changes in feelings of PO were typically described as being “slight” or "small”. ESO was only felt to add "slightly" (or not at all) to existing feelings of PO:

It (ESO) probably does to an extent (affect psychological ownership), but for me I guess I had such a strong feeling of ownership in the first place, it was so deep rooted that the share side of things, yes, it bolsters that but it didn't significantly improve it (EMI Participant, Company 4).

No, they are two separate things. They are totally separate (SAYE Participant, Company 8).

Pierce et al. (2003, p. 94) stated that whilst "there have been many attempts to identify the targets to which individuals become psychologically tied” there does not appear to be a 
theory of ownership targets. Employees in this study did not find it easy to differentiate between ownership targets, and often were unable to be any more specific than to say they felt ownership over the company as a whole, or their job. In some cases employees were able to identify certain projects, responsibilities, teams, or achievements, but few were able to be specific. The extract below demonstrates how one employee felt able to identify PO over tasks performed as part of his job, and the company as a whole.

When I think about the work, yes, I also think, "Oh I have got some options. The options do contribute a little bit to a sense of ownership over my tasks that I do, and (the company), feeling like, it is my company that I work for. (EMI Participant, Company 5).

The data show that the majority of employees felt that the organization provided them with autonomy, some freedom to make decisions, and an opportunity to have some influence at work - at least within their department or area of work. The lack of perceived impact on PO from ESO may reflect the possibility that in these companies, the low levels of work environment structure (providing opportunities for the routes to be satisfied: see O’Driscoll et al., 2006; Brown et al., 2013) were satisfying one or more of the routes to PO. Thus it is possible that pre-existing feelings of PO had a limiting effect on the influence ESO could have on PO.

\section{Perceptions of effects of ESO on attitudes and behaviours}

Twenty-one of the 37 employees interviewed felt that participating in an ESO scheme had caused a positive change (often described as small) in their attitudes and/or behaviours at work. Of these, 12 felt ESO affected their attitudes and/or behaviours without satisfying any 
of the routes to PO, and 13 reported that ESO had an impact without affecting PO. A range of different experiences signalled multiple possibilities of what employees may experience when they perceive ESO to have an impact on their attitudes and/or behaviours.

Continuance commitment (Allen \& Meyer, 1990) was the attitude most often reported as affected by ESO. In this type of commitment, employees make an assessment of the costs associated with leaving the organization. This is in contrast to affective commitment, characterized by positive feelings of identification with, attachment to, and involvement in, the organization (Meyer \& Allen, 1984). In general, the respondents reported that the scheme had made them more committed because they believed they might make money. In addition, about half of the employees interviewed (spread across all three schemes) felt that the ESO scheme would influence the amount of time they would stay in the company. The evidence however, did not suggest that employees were more likely to stay because ESO had led to a feeling of PO. Instead, explanations again referred to the financial incentives of ESO, and the motivation to remain to receive financial returns.

(Speaking about the financial gain that can be made) I suppose for me it [ESO] has actually given me more reason to stay... it makes you think about what you are doing, where you are going, and obviously if you decide to leave what are you actually going to lose (SAYE Participant, Company 8).

...if you feel your motivation waning you can remember that you do have these shares that could lead to some cash, and it boosts you. I would like to think it is there anyway, but, it does (EMI Participant, Company 4).

Contrary to Pierce et al.’s (1991) propositions (and other theoretical predictions of PO, e.g. Mayhew et al., 2007; O’ Driscoll et al., 2006; Van Dyne et al., 2004) few employees 
attributed attitudinal impact from the ESO scheme to feelings of PO at work. In only one case was ESO's impact on commitment (in this case affective commitment), felt to have worked via company-based PO. Six employees felt there was an impact on their motivation at work and two employees felt more job satisfaction as a result of participating in an ESO scheme. Employees indicated that rather than PO, the impact was caused by the possibility that they might make a financial return. Since only two employees felt greater levels of satisfaction, and neither linked this to PO, it is difficult to conclude that this study offers support for the literature hypothesizing ESO’s impact on employee satisfaction via PO (Pierce et al., 1991). Instead, the extrinsic satisfaction in these cases derived from the share options given to the individual (Odom, Boxx \& Dunn, 1990).

Two employees felt that the ESO scheme had influenced their work performance. One of these also reported that ESO affected PO. The findings offer little support for Pierce et al.’s (2004a) model, or Brown et al.’s (2013) findings which suggest ESO participation can lead to PO and a subsequent impact upon performance. The discrepancy may have occurred for a number of reasons. It may be that in this sample, the higher performing employees were more likely to participate in ESO. It appears likely from the data that employees perceived a weak connection between individual effort and reward (the '1/N problem') (Ben-Ner \& Jones, 1995), and wanted to use ESO for investment, rather than to feel part of the company as an employee-owner. These factors may have limited ESO’s capacity to have performance effects via PO.

Finally, in contrast to predictions in the research literature that attitudinal/behavioural effects emerge via ESO’s impact on PO and the routes to it, four employees described experiencing some of the routes to PO at work but not caused by ESO; felt ESO had not provided any experiences of the routes; and did not feel any PO at work (despite in some 
cases experiencing all three routes); yet still felt that ESO had a positive effect on their attitudes and/or behaviours.

\section{Employees' Experiences of ESO and the 'Psychological Ownership Routes'}

The experiences and feelings described by interviewees, allow us to compare whether theoretical assumptions and related theories make sense to ESO participants and fit with their own sense-making. Pierce et al. $(2001,2003)$ theory of 'PO routes' suggests that certain experiences at work are likely to produce feelings of PO. Table 2 shows where, based on employees' own interpretations, they experienced the routes to PO, PO itself, and the impacts of ESO on the routes to PO and on attitudes and behaviours.

Insert Table 2 about here

Employee descriptions did not suggest that they felt ESO’s impact on PO was working through any of the routes to PO (as hypothesized by Pierce et al., 2001; 2003). The lack of alternative explanations provided by employees (in this study and in previous research literature) of how ESO affects PO may reveal how difficult it is to articulate and distinguish between causes of PO. Where an impact was described, employees felt ESO had a direct impact on PO. We found only one employee who felt ESO's impact on PO worked through a route to PO. This employee reported an impact on his feelings of ownership toward the company, and that his enhanced interest (described to be caused by ESO) in understanding changes in the share price (the knowledge route) led to his feelings of PO: 
When I have got the scheme and I am saving each month and you see the share price moving you do sort of think, what are they doing, why is that happening, sort of, you obviously read in the papers or see in the news, so definitely (explaining why he felt psychological ownership over the company) (SAYE Participant, Company 8).

Not all employees who experienced PO at work believed that all three routes were satisfied, by ESO or any other factors. Six employees indicated that ESO affected feelings of PO but not via any of the routes. The data support suggestions made in the literature that PO can develop without all three routes being satisfied at work (see Pierce et al., 2003; VandeWalle et al., 1995; Van Dyne et al., 2004). But also, it seems that in some cases no routes at all are needed for PO to occur.

Overall, as Table 2 shows, three respondents (8\%) thought the control route was operating as a result of ESO, and none at all reported this for the investment of self route. 14 of the 37 interviewees (38\%) gave responses that indicated they felt the intimate knowledge route had been enhanced by their participation in ESO. Despite this, all three routes to PO were almost universally experienced and so was PO itself, especially job-based PO.

\section{Control}

In relation to the control route, ESO was rarely seen to create new feelings of control or influence over anything employees did not already feel they had some influence over. Where employees described an effect, it was only where employees felt they were already (prior to ESO participation) experiencing a feeling of control or influence at work, for example, over a certain responsibility, team of people or department: 
Erm, no I have always had that. It has had very little impact (EMI Participant, Company 6).

I think I have got more influence from working in the company than through owning shares (SIP Participant, Company 2).

Many employees in the study had received voting rights as an ESO participant, yet very few felt they had significantly more influence as a result. This quote reflects the limit of perceived control via voting rights:

Erm, yes (indicating ESO provided a feeling of control or influence at work), shareholders, obviously, can go to the shareholder AGM if you want to go...you have got, to a very small extent, an influence about what goes on and can say your bit (SAYE Participant, Company 7).

Across all schemes, the lack of evidence and the emphasis employees placed on this being a 'small impact' that 'would not change things a great deal', gave a strong overall impression that employees interpreted no significant impact from ESO on the control route. Furthermore, employees also felt that participating in the ESO scheme had not led them to desire more control or influence at work.

\section{Investment of the self}

With regards to the extent to which employees felt they invested themselves into their work/or a particular organizational target (reflected in the energy, time, effort, and attention employees felt they invested), all employees felt that they were already doing this as much as 
they could, and that the ESO schemes did not lead to any changes. Of all the routes, this seemed to be the one in which employees were most confident in concluding there was no impact.

Not really, I don't (invest any more time, effort, energy, attention), I feel like I am just a grain of sand...it (the SIP) does not bother me at all. I don't feel like a shareholder, I just feel like I have got some savings (SIP Participant, Company 2).

No, it wouldn't change anything (RE: The 'investment of the self' route). When I bought the first lot and the share value dropped significantly, they were almost worthless. It didn't really affect the way I felt (SIP Participant, Company 3).

In the context of this route, for many employees the ESO scheme was separate from what they did at work. Employees tended to indicate that they felt other organizational factors had more influence on these experiences. For example, some employees felt a sense of task significance in their jobs. Others felt that they would invest themselves into their job whether or not they were participating in an ESO scheme:

No, no. No, I think what I am doing I would have done anyway, even if there was no option scheme (EMI Participant, Company 6).

\section{Knowledge}

Of all the routes, relatively more employees described an impact on the knowledge route. Fourteen participants felt that because they were an SAYE, SIP or EMI participant they sought more information about the company, its performance, and the share price. 
I think, since I participated in the scheme I am more aware of the company globally and I think more about that as a business rather than just the UK business (SIP participant, Company 2).

It certainly makes me more interested in what the profits are and where they are coming from (SAYE Participant, Company 9).

Employees described the impact on this route to be a result of seeking more information themselves, rather than being given information they were legally entitled to as ESO participants or as shareholders. It was also clear that employees who could envisage making money from the scheme (particularly employees in C2 and C4) were more likely to feel that their interest in understanding the company had increased. Specific aspects mentioned included company strategy and reasons for changes in share price. Employees were also interested in knowing when the best time to sell shares would be, how much profit the company was making and how much money they were likely to make from the ESO scheme.

Although employees felt more knowledgeable about the company and share price movement as a result of ESO participation, their knowledge and understanding of how the ESO scheme worked was generally not felt to be good, echoing Tucker et al. (1989). Most employees stated that they did not feel they needed to understand the ESO scheme until they were able to ‘do something' with their shares/options and therefore needed to know how much they were worth, for example if they wanted to sell some, or were leaving the company, or if there was a change to the scheme. Employees indicated that the long term nature of ESO meant that it was easy to forget. In summary, participants' accounts of their experiences provide limited evidence that they felt the SAYE, SIP and EMI schemes satisfied the routes to PO as described by Pierce et al. 
(1991). The intimate knowledge route was the only one that a substantial number of participants (14) thought was enhanced by ESO. There was little evidence in this group that one scheme was more effective than another at satisfying any particular route (see Table 2). We conclude that, contrary to O’Driscoll et al.’s (2006) suggestion, when employees felt that one route was found to be satisfied by ESO they did not feel this led to the other routes also being satisfied. Also, contrary to predictions in the literature (e.g. Chi \& Han, 2008; Pierce et al., 1991; Pierce \& Rodgers, 2004a), we found that overall most participants describe little or no impact from ESO participation on the routes to PO.

\section{Why were few effects described?}

Two main explanations for ESO’s lack of perceived impact on the routes can be identified from employees' responses. The first relates to what the employees felt they were already experiencing at work, and how they would behave if they were not an ESO participant. Many employees felt that the opportunities to exert influence at work, obtain information, seek understanding of what was happening, and the energy, effort, time and attention they invested, were a result of other factors and were already being experienced prior to ESO participation. Where the ESO scheme was not felt to have affected the control or knowledge route, employees stated their jobs already offered some autonomy and responsibility. Employees also felt they would want to seek knowledge and understanding of issues relating to the company and would want to be involved and participate in decisions regardless of ESO membership. A clear example was found in C9, where more than any of the other companies in this study, the share price had fallen in the previous few years. Following this, employees felt they needed to be interested in the company (irrespective of SAYE participation) and needed to invest their time, effort, energy and attention in order to keep their jobs. 
(Knowledge route) I follow its performance pretty closely anyway. I don't think you can particularly say it is because of the scheme (SAYE Participant, Company 9). (Investment of the self route) ... from what you hear from around the company about what the shares are worth, you don't see much enthusiasm from people that have got quite a lot of shares (EMI Participant, Company 5).

The second possible explanation of why ESO was found to contribute little to the routes to PO may relate to employees’ interest in ESO as an investment. French (1987, p. 432) argued that "when ownership is treated by employee shareholders as an investment, it makes little sense to assume that shareholding invariably increases employees' desires for influence”. It was also suggested by Pierce at al. (1991) that a financial orientation may weaken the relationship between ESO and PO. Employees felt that ESO did not inspire them to want more control or influence and was primarily viewed as investment.

"It sounds incredibly shallow, but yeah, I mean, ultimately you are looking at it as it is an additional reward, an additional top up to what you get paid, and of course I want to pay off my mortgage early, I want to retire early, you know and that all contributes to that" (EMI Participant, Company 4).

Similar barriers appeared to prevent the knowledge route from being satisfied. In C5 and C6, where no effect at all was reported for this route, there was disillusionment with the long wait until shares could be exercised in the EMI scheme.

Overall, the lack of perceived effect on the routes to PO may be a result of the schemes being unable (or not being perceived to) provide the characteristics of ownership (equity, information and influence). During interviews it was clear that ESO was less about 
ownership, and more about investment. Employees did not expect to have any ownership rights as a result of participating. Furthermore, employees did not suggest that the changes (often described as small) in the PO routes attributable to ESO translated into feelings of PO, or into changes in their attitudes or behaviours.

\section{Conclusions and Research Recommendations}

This study provides insights into how employees participating in ESO schemes in the UK interpret ESO and the connections between it and PO. Our qualitative approach contrasts with the more frequently taken survey approach in the ESO and PO literature, and uncovers a range of diverse employee interpretations. Overall, employees in this study felt that the ESO schemes had little effect on PO or the organizational features anticipated to give rise to PO. The partial exception to this was the intimate knowledge route.

Kaarsemaker et al. (2010) suggested that in mainstream ESO, employees may be more financially orientated and have a weaker sense of ownership than in majority ESO. Our findings support this assertion, reflecting Klein’s (1987) extrinsic model of ESO, and in our study the majority of employees perceived only a small impact between ESO and PO. Our findings also show that some employees in all three schemes described some impact on their thoughts, feelings and behaviours at work. This included (a) cases where employees felt no PO at work (before or after ESO participation) and (b) cases where employees reported feeling pre-existing PO, caused by factors other than ESO. The study found that PO played little or no part in employees’ explanations of how the ESO scheme impacted upon their attitudes or behaviours.

The literature suggests that, to have an impact, ESO does not have to provide all of the ownership rights (equity, influence, information) or to satisfy all the routes to PO. Even so, in this study, we found that ESO had very little to do with ownership in the minds of 
employees. Employees did not appear to regard ESO as providing experiences of the three ownership rights, or the routes to PO which parallel these. In almost all cases, the routes were felt by employees to have been satisfied at work by other factors. ESO added to some of these experiences in a small way.

Why have our findings generally drawn a blank regarding PO and processes surrounding it? It may be that the models set out by Pierce et al. (1991, 2001, 2003); Pierce and Rodgers (2004a), and Chi and Han (2008) are more likely to play out in practice in situations where ESO is introduced into environments where employees are not already experiencing the routes to PO or feeling any PO at all. A situation like this might be very rare partly because companies that provide little or no opportunity to experience PO may not be interested enough in employee incentives to offer ESO. This would mean that Pierce and colleagues' models do not reflect the subjective experience of participating in ESO in conditions normally found in organizations. These models may be more likely to be reflected in employees' accounts where ESO is perceived primarily as a way of having ownership in the company rather than an investment mechanism. Our data were collected in the aftermath of the financial crash of the late 2000s, which may have led people to view their employment relationships in terms of security and material reward, leaving little room for more psychological forms of attachment. The findings in this study therefore do not rule out the possibility that ESO can satisfy some or all of the routes, or that PO can emerge from ESO participation and lead to other effects.

From our analysis of employees' explanations, a number of findings run counter to the positivist causal models described in the PO and ESO research literature. This does not necessarily mean these models are 'wrong', only that they do not match well with the selfreported experience in our study. People may not have conscious access to all the causal processes that govern their attitudes and behaviours (Nisbett \& Wilson, 1977). Nevertheless, 
the accounts given by our respondents are sufficiently clear to cast doubt on models of mainstream ESO and PO.

If PO can lead to attitudinal and behavioural outcomes, the question emerges whether companies would be better advised to concentrate on developing feelings of PO, rather than providing mainstream share ownership schemes. PO is not necessarily weaker without ESO and whilst ESO may possibly produce more significant effects when it satisfies the routes to PO, it seems unlikely that employees expect ESO to provide the characteristics of ownership. The evidence in support of attitudinal and behavioural consequences from PO is generally positive, in contrast to the very mixed evidence in support of ESO's psychological impact found in our study and the literature generally. The costs and benefits of this (e.g. the cost of operating an ESO scheme versus the potential attitudinal, behavioural and productivity benefits of PO) would benefit from future research.

None of the 37 employees in our study felt that participating in the ESO scheme led them to invest more attention, effort, time or energy into what they did at work, and few reported that the scheme gave them additional control, opportunities or influence.

\section{Limitations}

Some evidence suggests that people sometimes misperceive and misinterpret data, make too much of ambiguous data, and deduce biased interpretations (seeing what we want to see) (Gilovich, 1991). Whether ticking boxes in answer to questions in a quantitative survey or providing verbal explanations during an interview, we know that humans are susceptible to this. Similarly, respondents in positivist or interpretivist studies may not be able to identify the relationships between feelings they report. Nisbett and Wilson (1977) proposed that when people attempt to report on their cognitive processes they do not do so on the basis of any true introspection. Instead, their reports are based on a priori, implicit causal theories, or 
judgments about the extent to which a particular stimulus is a plausible cause of a given response. Similarly, Read et al. (1989) claim that people construct scenarios that make sense of a sequence of events; and they often impose a causal structure on those events as a way of making them meaningful. It is possible that interviewees may struggle to explain, or contemplate, the reasons why they felt a certain way or made a particular decision. In this phenomenological study we have viewed the perceptions of ESO and PO to be "partial, subjective, and incomplete; it does not (necessarily) mirror reality” (Willis, 2007, p. 172). 


\section{References}

Avey, J., Avolio, B., Crossley, C., \& Luthans, F. (2009). Psychological ownership: Theoretical extensions, measurement, and relation to work outcomes. Journal of Organizational Behavior, 30, 173-191. doi: 10.1002/job.583

Ben-Ner, A., \& Jones, D. (1995). Employee participation, ownership, and productivity: A theoretical framework. Industrial Relations: A Journal of Economy and Society, 34, 532-53. doi: 10.1111/j.1468-232X.1995.tb00387.x

Bernhard, F., \& O'Driscoll, M. P. (2011). Psychological ownership in small family-owned businesses: Leadership style and nonfamily-employees’ work attitudes and behaviors. Group \& Organization Management, 36, 345-384. doi: $10.1177 / 1059601111402684$

Blasi, J., Conte, M., \& Kruse, D. (1996). Employee stock ownership and corporate performance among public companies. Industrial and Labor Relations Review, 50, 60-79. doi: $10.2307 / 2524389$

Braun, V., \& Clarke, V. (2006). Using thematic analysis in psychology. Qualitative Research in Psychology, 3,77-101. doi: 10.1191/1478088706qp063oa

Brown, G., Pierce, J. L., \& Crossley, C. (2013). Toward an Understanding of the Development of Ownership Feelings. Journal of Organizational Behavior. Online version of record published before inclusion in an issue. doi: 10.1002/job.1869

Bryman, A. (2008). Social Research Methods. Oxford University Press.

Buchko, A. (1992). Effects of employee ownership on employee attitudes: a test of three theoretical perspectives, Work and Occupations, 19, 59-78. doi: 10.1177/0730888492019001004 
Caramelli, M. (2011). Towards a Theory of the Attitudinal Effects of Employee Stock Ownership. INSEEC Business School, Paris, France. Retrieved from http://smlr.rutgers.edu/smlr/sites/smlr/files/.

Cassell, C., \& Symon, G. (2011). Assessing 'good' qualitative research in the work psychology field: A narrative analysis. Journal of Occupational and Organizational Psychology, 84(4), 633-650.

Chi, N., \& Han, T. (2008). Exploring the linkages between formal ownership and psychological ownership for the organization: The mediating role of organizational justice. Journal of Occupational and Organizational Psychology, 81, 691-711. doi: 10.1348/096317907X262314

Chiu, W., Hui, H., \& Lai, G. (2007). Psychological ownership and organizational optimism amid China's corporate transformation: effects of an employee ownership scheme and a management-dominated board. International Journal of Human Resource Management, 18, 303-320. doi: 10.1080/09585190601102539

Culpepper, R., Gamble, J., \& Blubaugh, M. (2004). Employee stock ownership schemes and three-component commitment. Journal of Occupational and Organizational Psychology, 77, 155-170. doi: 10.1348/096317904774202126

Deputy Prime Minister’s Cabinet Office (2012) Deputy Prime Minister's speech at Mansion House. Retrieved from http://www.dpm.cabinetoffice.gov.uk/news/deputy-primeminister-s-speech-mansion-house.

Fenton-O'Creevy, M., Soane, E., Nicholson, N., \& Willman, P. (2011). Thinking, feeling and deciding: The influence of emotions on the decision making and performance of traders. Journal of Organizational Behavior, 32, 1044-1061. doi: 10.1002/job.720

Finance Act 2000, Schedule 8, Part 2. London: HMSO.

French, J. (1987). Employee perspectives on stock ownership: financial investment or 
mechanism of control?, Academy of Management Review, 12, 427-435. doi:10.5465/AMR.1987.4306558

French, J., \& Rosenstein, J. (1984). Employee ownership, work attitudes, and power relationships. Academy of Management Journal, 27, 861-869. doi: 10.2307/255883

Freeman, S. (2007). Effects of ESOP adoption and employee ownership: 30 years of research and experience. Working Paper No. 07-01, University of Pennsylvania, Philadelphia, PA. Retrieved from www.aeoa.org.au/docs/0024/ESOPs\%2030\%20years\%20of\%20research.pdf

Furby, L. (1978). Possessions: toward a theory of their meaning and function throughout the life cycle. In P. Baltes (Ed.), Life Span Development and Behavior (pp. 297 - 336), New York: Academic Press.

Gamble, J. E., Culpepper, R., \& Blubaugh, M. G. (2002). ESOPs and employee attitudes: The importance of empowerment and financial value. Personnel Review 31, 9-26. doi $10.1108 / 00483480210412391$

Gilovich, T. (1991). How we Know What isn't so: The Fallibility of Human Reason in Everyday Life. New York: Free Press.

Gioia, D. A., Corley, K. G., and Hamilton, A. L. (2013). 'Seeking qualitative rigor in inductive research notes on the Gioia methodology’. Organizational Research Methods, 16, pp. 15-31.

Giorgi, A., Phenomenological Psychology, in: Smith, J. A., Harré, R., \& Van Langenhove, L. (Eds.). (1995). Rethinking psychology (Vol. 3). Sage.

Hammer, T., Stern, R., \& Gurdon, R. (1982). Worker ownership and attitudes toward Participation. In F. Lindenfeld \& J. Rothschild-Whitt (Ed). Workplace democracy and social change (pp. 87 - 108). Boston, MA: Porter Sargent Publishers. 
Jones, D., \& Kato, T. (1995). The productivity effects of employee stock-ownership schemes and bonuses: evidence from Japanese panel data. The American Economic Review, 85, 391-414. Retrieved from http://www.jstor.org/stable/2118180

Kaarsemaker, E., Pendleton, A., \& Poutsma, E. (2009). Employee Share Ownership Plans: A Review. York, UK: University of York. Retrieved from http://eprints.whiterose.ac.uk/8883/. Accessed 22 February 2013.

Kaarsemaker, E., Pendleton, A., \& Poutsma, E. (2010). Employee share ownership schemes: a review. In A. Wilkinson, M. Marchington, P. Gollan, \& D. Lewin (Eds.). Oxford handbook of participation in organizations (pp. 315-338). Oxford: Oxford University Press.

Klein, K. (1987). Employee stock ownership and employee attitudes: a test of three models. Journal of Applied Psychology, 72, 319-332. doi: 10.1037/0021-9010.72.2.319

Knyght, P., Kouzmin, A., Kakabadse, N., \& Kakabadse, N. (2010). Auditing employee ownership in a neo-liberal world. Management Decision, 48, 1304-1323. doi: $10.1108 / 00251741011076807$

Kruse, D. (1984). Employee Ownership and Employee Attitudes: Two Case Studies. Norwood, PA: Norwood Editions.

Kruse, D. (2002). Research evidence on prevalence and effects of employee ownership. Presented in testimony to the Subcommittee on Employer-Employee Relations, U.S. House of Representatives. http://ownershipassociates.com/kruse.shtm.

Lincoln, Y. S., \& Guba, E. G. (1985). Naturalistic inquiry (Vol. 75). Sage.

Long, R. (1978a). The relative effects of share ownership vs. control on job attitudes in an employee-owned company. Human Relations, 31, 753-763.

doi: $10.1177 / 001872677803100901$

Long, R. (1978b). The effects of employee ownership on organizational identification, 
employee job attitudes, and organizational performance: A tentative framework and empirical findings', Human Relations, 31, 29-48. doi: 10.1177/001872677803100102

Long, R. (1982). Worker ownership and job attitudes: A field study. Industrial Relations, 21, 196-215. doi: 10.1111/j.1468-232X.1982.tb00228.x

Lopez, K. A., and Willis, D. G. (2004). 'Descriptive versus interpretive phenomenology:

Their contributions to nursing knowledge’. Qualitative Health Research, 14, pp.726-735.

McAlearney, A. S. (2006). Leadership development in healthcare: a qualitative study. Journal of Organizational Behavior, 27, 967-982. doi: 10.1002/job.417

Mayhew, M., Ashkanasy, N., Bramble, T., \& Gardner, J. (2007). A study of the antecedents and consequences of psychological ownership in organizational settings. The Journal of Social Psychology, 147, 477-500. doi: 10.3200/SOCP.147.5.477-500

McCarthy, D., Reeves, E., \& Turner, T. (2010). Can employee share-ownership improve employee attitudes and behavior?. Employee Relations, 4, 382-395.

doi: 10.1108/01425451011051604

McCarthy, D., \& Palcic, D. (2012). The impact of large-scale employee share ownership schemes on labor productivity: the case of Eircom. The International Journal of Human Resource Management, 23, 3710-3724. doi: 10.1080/09585192.2012.655762

Meng. R., Ning, X., Zhou, X., \& Zhu, H. (2010). Do ESOPs enhance firm performance? Evidence from China’s reform experiment. Journal of Banking and Finance, 34, 1541-1551. doi:10.1016/j.jbankfin.2010.11.004

Meyer, J., \& Allen, N. (1984). Testing the ‘side bet theory’ of organizational commitment: Some methodological considerations. Journal of Applied Psychology, 69, 372-378. doi: 10.1037/0021-9010.69.3.372

Miles, M., \& Huberman, A. (1994). Qualitative Data Analysis. London: Sage Publications. 
Millward, L. J. (2006). The transition to motherhood in an organizational context: An interpretative phenomenological analysis. Journal of Occupational and Organizational Psychology, 79(3), 315-333.

Nisbett, R. E., \& Wilson, T. D. (1977). Telling more than we can know: Verbal reports on mental processes. Psychological Review, 84, 231-259. doi: 10.1037/0033295X.84.3.231

Nuttall, G. (2012). Sharing Success: The Nuttall Review of Employee Ownership. Department for Business, Innovation and Skills (UK). Ref: BIS/12/933.

Odom, R. Y., Boxx, W. R., \& Dunn, M. G. (1990). Organizational cultures, commitment, satisfaction, and cohesion. Public Productivity \& Management Review, 14, 157-169. doi: $10.2307 / 3380963$

O’Driscoll, M., Pierce, J., \& Coghlan, A. (2006). The psychology of ownership: work environment structure, organizational commitment, and citizenship behavior. Group and Organization Management, 31,388-416. doi: 10.1177/1059601104273066

Pendleton, A., Wilson, N., \& Wright, M/ (1998). The perception and effects of share ownership: empirical evidence from employee buy-outs. British Journal of Industrial Relations, 36, 99-124. doi: 10.1111/1467-8543.00082

Pendleton, A. (2001). Employee ownership, participation and governance. A study of ESOPs in the UK. London: Routledge.

Pendleton, A., \& Robinson, A. (2011). Employee share ownership and human capital development: Complementarity in theory and practice. Economic and Industrial Democracy, 32, 439-457. doi: 10.1177/0143831X10387650

Pierce, J., Rubenfeld, S., \& Morgan, S. (1991). Employee ownership: a conceptual model of process and effects. Academy of Management Review, 16, 121-144.

doi:10.5465/AMR.1991.4279000 
Pierce, J., Kostova, T., \& Dirks, K. (2001). Towards a theory of psychological ownership in organizations. Academy of Management Review, 26, 298-310. doi:10.5465/AMR.2001.4378028

Pierce, J., Kostova, T., \& Dirks, K. (2003). The state of psychological ownership: integrating and extending a century of research. Review of General Psychology, 7, 84-107. doi: 10.1037/1089-2680.7.1.84

Pierce, J., \& Rodgers, L. (2004a). The psychology of ownership and worker-owner productivity. Group and Organization Management, 29, 560-587. doi: $10.1177 / 1059601103254270$

Pierce, J., O’Driscoll, M., \& Coghlan, A. (2004b). Work environment structure and psychological ownership: the mediating effects of control. The Journal of Social Psychology, 144, 507-534. doi: 10.3200/SOCP.144.5.507-534.

Poppleton, S., Briner, R. B., \& Kiefer, T. (2008). The roles of context and everyday experience in understanding work-non-work relationships: A qualitative diary study of white-and blue-collar workers. Journal of Occupational and Organizational Psychology, 81(3), 481-502.

Poutsma, E., Kalmi, P., \& Pendleton, A. (2006). The relationship between financial participation and other forms of employee participation: new survey evidence from Europe. Economic and Industrial Democracy, 27, 637-668. doi: 10.1177/0143831X06069006

Read, S. J., Druian, P. R., \& Miller, L. C. (1989). 'The role of causal sequence in the meaning of actions'. British journal of social psychology, 28(4), pp. 341-351.

Rubin, H., \& Rubin, I. (2005). Qualitative Interviewing: The Art of Hearing Data. London: Sage Publications. 
Rudmin, F., \& Berry, J. (1987). Semantics of ownership: A free-recall study of property. The Psychological Record, 37, 257-268.

Selvarajan, T., Ramamoorthy, N., Flood, P., \& Rowley, P. (2006). Employee stock option scheme and employee attitudes: A test of extrinsic versus intrinsic models. International Journal of Sociology and Social Policy, 26, 245-254. doi: 10.1108/01443330610674288

Sengupta, S. (2008). The impact of employee-share-ownership schemes on performance in unionized and non-unionized workplaces. Industrial Relations Journal, 39, 170-190. doi: 10.1111/j.1468-2338.2007.00483.x

Sengupta, S., Pendleton, A., \& Whitfield, K. (2010). How Employee Share Ownership Structure shapes the ESO/Performance relationship: An analysis using WERS 2004. British Academy of Management Conference, University of Sheffield, UK.

Sengupta, S., Whitfield, K., \& McNabb, R. (2007). Employee share ownership and performance: golden path or golden handcuffs?. The International Journal of Human Resource Management, 18, 1507-1538. doi: 10.1080/09585190701502620

Sesil, J., Kroumova, M., Blasi, J., \& Kruse, D. (2002). Broad-based employee stock options in US ‘new economy’ firms. British Journal of Industrial Relations, 40, 273-294. doi: 10.1111/1467-8543.00232

Sieger, P., Zellweger, T., \& Aquino, K. (2013). Turning agents into psychological principals: Aligning interests of non-owners through psychological ownership. Journal of Management Studies, 50, 361-388. doi: 10.1111/joms.12017

Tucker, J., Nock, S., \& Toscano, D. (1989). Employee ownership and perceptions of work: the effect of an employee stock ownership scheme. Work and Occupations, 16, 26-46. doi: $10.1177 / 0730888489016001002$

VandeWalle, D., Van Dyne, L., \& Kostova, T. (1995). Psychological ownership: an empirical 
examination of its consequences. Group and Organization Management, 20, 210-226. doi: $10.1177 / 1059601195202008$

Van Dyne, L., \& Pierce, J. (2004). Psychological ownership and feelings of possession: three field studies predicting employee attitudes and organizational behavior. Journal of Organizational Behavior, 25, 439-460. doi: 10.1002/job.249

Wagner, S., Parker, C., \& Christiansen, N. (2003). Employees that think and act like owners: effects of ownership beliefs and behaviors on organizational effectiveness. Personnel Psychology, 56, 847-871. doi: 10.1111/j.1744-6570.2003.tb00242.x

Willis, J. W. (2007). Foundations of qualitative research: Interpretive and critical approaches. Sage.

\section{Appendix 1}

Three UK Employee Share Ownership Schemes

\begin{tabular}{|l|l|}
\hline $\begin{array}{l}\text { ESO } \\
\text { Scheme }\end{array}$ & Description \\
\hline $\begin{array}{l}\text { Save as You } \\
\text { Earn } \\
\text { (SAYE) }\end{array}$ & $\begin{array}{l}\text { Employees participating in the SAYE have the option to buy shares in the } \\
\text { company. An exercise price is fixed when the option is granted. In an SAYE } \\
\text { scheme, employees can save between } £ 5 \text { and } £ 250 \text { per month, for three, five } \\
\text { chooses to exercise their options. The employee receives the proceeds of the } \\
\text { SAYE contract (savings) if the shares are not exercised. }\end{array}$ \\
\hline $\begin{array}{l}\text { Share } \\
\text { Incentive }\end{array}$ & $\begin{array}{l}\text { Employees become shareholders as soon as they start participating in the SIP. } \\
\text { Plan (SIP) } \\
\text { The SIP provides shares in three possible ways: (1) Partnership shares: up to } \\
\text { Insurance earnings; or (if less) up to 10 per cent of gross salary. (2) Free } \\
\text { shares: employees can be given up to } £ 3,000 \text { worth of shares each year from } \\
\text { their employer; (3) Matching shares: up to 2 free shares can be given to } \\
\text { employees for every partnership share bought. Performance conditions can } \\
\text { also be attached to the award of shares in the SIP. }\end{array}$ \\
\hline
\end{tabular}




\begin{tabular}{|l|l|}
\hline & $\begin{array}{l}\text { Intended to help small, higher risk independent trading companies, in the EMI } \\
\text { scheme, employees can be selected by employers (this is not an all-employee } \\
\text { Enterprise } \\
\text { Management } \\
\text { Incentives } \\
\text { (EMI) }\end{array}$ \\
$\begin{array}{l}\text { worth up to } £ 120,000 \text {. Once granted EMI options, employees cannot be } \\
\text { granted any more EMI options until three years have passed (from the date of } \\
\text { the last grant). There is no set period of exercise, and options can be granted at } \\
\text { any exercise price. }\end{array}$ \\
\hline
\end{tabular}

\section{Figure 1}

Research objective: To explore how employees describe the relationships between ESO scheme participation, attitudes and behaviours at work, and feelings of psychological ownership.

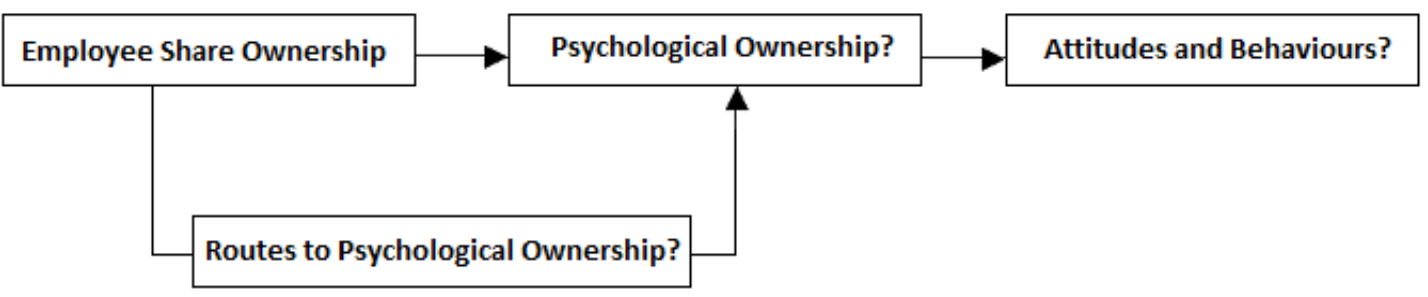




\section{Psychological Ownership and Employee Share Ownership}

\section{Table 1}

Sample criteria and characteristics of the chosen companies and employees

\begin{tabular}{|c|c|c|c|c|c|c|c|c|c|}
\hline & Company 1 & Company 2 & Company 3 & Company 4 & Company 5 & Company 6 & Company 7 & Company 8 & Company 9 \\
\hline ESO plan & SIP & SIP & SIP & EMI & EMI & EMI & SAYE & SAYE & SAYE \\
\hline Industry & Real Estate & $\begin{array}{c}\text { Market } \\
\text { Research }\end{array}$ & $\begin{array}{c}\text { Biology/ } \\
\text { Consumer } \\
\text { Care }\end{array}$ & Care Service & $\begin{array}{l}\text { Neuroscience } \\
\text { Research }\end{array}$ & $\begin{array}{l}\text { Management } \\
\text { Consultancy }\end{array}$ & $\begin{array}{c}\text { Tele- } \\
\text { communications }\end{array}$ & Retail & $\begin{array}{l}\text { Financial } \\
\text { Services }\end{array}$ \\
\hline $\begin{array}{l}\text { Number of } \\
\text { Employees }\end{array}$ & 42 & 850 & 3500 & 850 & 22 & 11 & 105,000 & 75,000 & 204,200 \\
\hline $\begin{array}{l}\text { ESO plan(s) in } \\
\text { place }\end{array}$ & SIP & SIP & SIP; SAYE & EMI; SAYE & EMI & EMI & SAYE; SIP & SAYE & SAYE; SIP \\
\hline $\begin{array}{l}\text { Age of } \\
\text { Business (yrs) }\end{array}$ & $10-15$ & $15-20$ & $15-20$ & $1-5$ & $5-10$ & $1-5$ & $20+$ & $20+$ & $20+$ \\
\hline \multicolumn{10}{|c|}{ Employees Interviewed } \\
\hline Male & 2 & 2 & 2 & 3 & 2 & 3 & 4 & 1 & 2 \\
\hline Female & 2 & 2 & 3 & 1 & 2 & 1 & 0 & 3 & 3 \\
\hline \multicolumn{10}{|c|}{ Length of Employment (yrs) } \\
\hline Up to 3 & 1 & 1 & 1 & 0 & 3 & 3 & 1 & 0 & 0 \\
\hline $\begin{array}{l}\text { More than } 3 \\
\text { and up to } 10\end{array}$ & 3 & 2 & 2 & 2 & 1 & 1 & 1 & 0 & 1 \\
\hline More than 10 & 0 & 1 & 1 & 2 & 0 & 0 & 2 & 4 & 4 \\
\hline \multicolumn{10}{|c|}{ Gross Earnings $(£)$} \\
\hline Up to 24,999 & 1 & 0 & 3 & 0 & 1 & 0 & 0 & 2 & 0 \\
\hline $\begin{array}{l}25,000- \\
54,999\end{array}$ & 3 & 2 & 1 & 2 & 2 & 2 & 1 & 2 & 3 \\
\hline $55,000+$ & 0 & 2 & 0 & 2 & 1 & 2 & 3 & 0 & 2 \\
\hline
\end{tabular}




\section{Psychological Ownership and Employee Share Ownership}

\section{Table 2}

Overview of employee experiences related to ESO and psychological ownership (PO): a plan by plan comparison

\begin{tabular}{|c|c|c|c|c|}
\hline $\begin{array}{l}\text { Experiences as reported by } \\
\text { employees during } \\
\text { interviews }\end{array}$ & $\frac{\text { SIP }}{(N=12)}$ & $\frac{\underline{E M I}}{(\mathrm{~N}=12)}$ & $\frac{\text { SAYE }}{(N=13)}$ & $\frac{\text { Total }}{(\mathrm{N}=37)}$ \\
\hline \multicolumn{5}{|l|}{ The control route to PO* } \\
\hline Felt at work & 10 & 12 & 11 & 33 \\
\hline Enhanced by ESO & 1 & 1 & 1 & 3 \\
\hline \multicolumn{5}{|l|}{$\begin{array}{l}\text { The intimate knowledge } \\
\text { route to PO** }\end{array}$} \\
\hline Felt at work & 11 & 12 & 13 & 36 \\
\hline Enhanced by ESO & 6 & 3 & 5 & 14 \\
\hline \multicolumn{5}{|l|}{$\begin{array}{l}\text { The investment of the self } \\
\text { route to } \mathrm{PO}^{* * *}\end{array}$} \\
\hline Felt at work & 12 & 12 & 13 & 37 \\
\hline Enhanced by ESO & 0 & 0 & 0 & 0 \\
\hline \multicolumn{5}{|l|}{ Company based PO } \\
\hline Felt at work & 9 & 9 & 8 & 26 \\
\hline Enhanced by ESO... & 2 & 3 & 3 & 8 \\
\hline via one or more routes & 0 & 0 & 1 & 1 \\
\hline \multicolumn{5}{|l|}{ Job based PO } \\
\hline Felt at work & 9 & 6 & 8 & 23 \\
\hline Enhanced by ESO... & 0 & 2 & 4 & 6 \\
\hline via one or more routes & 0 & 0 & 0 & 0 \\
\hline $\begin{array}{l}\text { Impact of ESO on attitudes } \\
\text { and/or behaviours }\end{array}$ & 7 & 6 & 8 & 21 \\
\hline $\begin{array}{l}\text { Traceable path ESO to PO } \\
\text { to attitudes/behaviours }\end{array}$ & 1 & 0 & 2 & 3 \\
\hline
\end{tabular}

*‘The control Route’: The amount of control/influence an employee has over a particular organizational target.

**‘The intimate knowledge route’: The extent to which the employee intimately knows a particular organizational target.

***‘The investment of the self route': The extent to which an individual employee invests themselves into their work/or a particular organizational target. 